\title{
Tropaeolum Mosaic Potyvirus (TropMV) Reduces Yield of Andean Mashua (Tropaeolum tuberosum) Accessions
}

\author{
Rejane L. Guimarães ${ }^{1}$ and Hector E. Flores \\ The Pennsylvania State University, Intercollege Program in Plant Physiology, \\ 313 Wartik Lab, University Park, PA 16802
}

Additional index words. Nasturtium, tuberization, socio-economic, productivity

\begin{abstract}
Quechua farmers have cultivated mashua (Tropaeolum tuberosum Ruiz \& Pavon) and other tuber crops for thousands of years. The practice of trading seed tubers may have contributed to dispersal of viral diseases, such as the tropaeolum mosaic virus (TropMV). We surveyed 17 accessions of mashua collected from Quechua farmers in the provinces of Cuzco and Ayacucho, Peru. Most cross-reacted with the TropMV antibody and showed viral disease symptoms. Significant differences were observed between accessions from Cuzco and Ayacucho, with respect to virus infection and tuber yield under greenhouse conditions. Of the accessions from Cuzco, $87 \%$ displayed viral symptoms, while only $22 \%$ from Ayacucho showed symptoms. Fewer tubers from Cuzco generated mature plants. In turn, those mature plants produced lower tuber yields. The practice of trading seed tubers may be advantageous for promoting crop diversity but can be harmful when diseased seed tubers are being traded. A program to generate and distribute virus-free seed tubers among Andean farmers would contribute to higher crop yields while preserving local customs and crop diversity.
\end{abstract}

Mashua (Tropaeolum tuberosum Ruiz \& Pavon), a member of the Tropaeolum (Nasturtium) family, is one of the most intensively cultivated root and tuber crops in the Andean region. Mashua tubers are prized for their mustard-like flavor. The tubers are very nutritious, with high levels of ascorbic acid, proteins and starch (Flores et al., 2003). Andean farmers cultivate a great diversity of mashua cultivars at elevations of 2,000 to 4,000 $\mathrm{m}$ above sea level. Along with potato, mashua is one of highest yielding Andean root and tuber crops. It is also appreciated for its medicinal, nematicidal and insecticidal properties (Arbizu and Tapia, 1994; National Research Council, 1989). Reduced interest in growing mashua in recent years has been ascribed to great losses in productivity, which are attributed to viral diseases (CIP, 1994; National Research Council, 1989).

The Tropaeolum mosaic potyvirus(TropMV) appears to be a major disease of mashua. Delhey and Monasterios (1977) were the first to report a mosaic disease of mashua in Bolivia, but no identification was made. More recently, Soria et al. (1998) assigned the name tropaeolum mosaic virus to the causal agent of a mosaic disease of mashua, and serological features indicated that the virus may belong to the potyviridae family.

Received for publication 8 Aug. 2003. Accepted for publication 15 Sept. 2004. The authors are thankful to Marleni Ramires for providing the mashua accessions, Thomas A. Evans for the monoclonal antibody and critical revision, and James Myers for assistance with statistical analysis and critical revision. This study was funded by the McKnight Foundation and the Plant Physiology Program, University of Pennsylvania.

${ }^{1}$ To whom reprint requests should be sent. Present address: Elemental Gardens, 318 W. 41st Ave. San Mateo, CA 94403; e-mail rejaneg@hotmail.com.
These authors reported the disease symptoms as vein clearing, leaf distortion and necrosis. TropMV was isolated from mashua, but other plant species such as Nicotiana benthamiana, N. debneyi, N. rustica, N. occidentalis, Gomphrena globosa and Chenopodium quinoa may be mechanically infected by the virus (Soria et al., 1998). Tropaeolum mosaic virus, sometimes called nasturtium mosaic virus, also infects Tropaeolum majus and Zinnia elegans and has been detected in the United Kingdom (Smith, 1950), U.S. (Jensen, 1950), South Africa (Da Graça and Martin, 1977), and different regions of South America (Silberschmidt, 1953; Soria et al., 1998). Transmission is thought to occur via aphids (Jensen, 1950).

Most mashua accessions studied at the Santa Catalina Experimental Station in Quito, Ecuador, were infected with TropMV (Soria et al. 1998). It is possible that many of the cultivars used by the Andean farmers are virusinfected and that infected seed tubers might have been propagated for centuries, leading to lower crop production in the high Andes. Indian groups, such as the Quechuas, have long traded mashua tubers and other crops in local markets. This custom may have contributed to the dissemination and perpetuation of viral diseases. We hypothesized that mashua seed tubers collected from Quechua farmers may be contaminated with TropMV virus, which in turn results in lower productivity. To test our hypothesis, we surveyed 17 mashua accessions from local Quechua markets in Peru for TropMV and evaluated their tuber yield under greenhouse conditions.

\section{Materials and Methods}

Plant material. Tubers were collected between 1997 and 1998 in Cuzco and Ayacucho, Peru, from grower markets in the communities of Ccorao, Chawaitiri and Paruro (Cuzco) and from San Jose de Arizona (Ayacucho) (Table 1). Cuzco city is at an elevation of $3400 \mathrm{~m}$ and Ayacucho city is at $2800 \mathrm{~m}$. The tubers were brought to Pennsylvania State University and accession letters were assigned to each morphotype based on origin and Quechua farmers' description (Table 1). Tubers were either stored at $4{ }^{\circ} \mathrm{C}$ until they began sprouting, or frozen for subsequent ELISA tests and protein analysis.

Tuber yield assessment. After incubation at $4{ }^{\circ} \mathrm{C}$ for about $8 \mathrm{~d}$, the sprouting tubers were planted in $10-\mathrm{L}$ pots, one tuber per pot, containing an all purpose commercial potting soil mixture (Schultz Co., St. Louis, Mo.). Plants were grown in greenhouse benches undernatural light levels at temperatures ranging from 16 to $28^{\circ} \mathrm{C}$. Plants were manually watered two times a week with no addition of fertilizer to the pots. Because the plants were very susceptible to white flies, thrips and aphids, they were sprayed with a dilute solution of orthene, $3.8 \mathrm{~L} / 9.3 \mathrm{~m}^{2}$, every 2 weeks to control insect pests.

Experiments were designed as two randomized blocks with five pots of each accession per block. Plants were planted in July of 1998 and tuberization occurred between November and February. Tubers were collected in February and nondestructively analyzed for tuber yields.

Table 1. Mashua accessions from several regions of Peru and described by local common names.

\begin{tabular}{lll}
\hline Mashua accession & Quechua name & Origin (Community) \\
\hline AA & Yana ñahui & San Jose de Arizona, Ayacucho \\
BDE & Yana ñahui & San Jose de Arizona, Ayacucho \\
CC & Yana añu & San Jose de Arizona, Ayacucho \\
GG & $--{ }^{z}$ & San Jose de Arizona, Ayacucho \\
HH & Cheej che añu & San Jose de Arizona, Ayacucho \\
II & Huashkar añu & San Jose de Arizona, Ayacucho \\
MN & Huacastia añu & San Jose de Arizona, Ayacucho \\
NN & --- & San Jose de Arizona, Ayacucho \\
S/C & Q'ellu & San Jose de Arizona, Ayacucho \\
Acu & Yana ñahui & Ccorao, Cuzco \\
Bcu & Puca añu & Ccorao, Cuzco \\
Dcu & Zapallu añu & Ccorao, Cuzco \\
Fcu & Wakak & Chawaitiri, Cuzco \\
Jcu & Papa añu & Ccorao, Cuzco \\
Kcu & Yana & Ccorao, Cuzco \\
Qcu & Puca ñahui & Paruro, Cuzco \\
Qcu & Yacuar huacac & Ccorao, Cuzco \\
\hline
\end{tabular}

${ }^{2}$ No name recorded. 
The number and fresh weight of tubers were determined for each accession. Statistical tests included analysis of variance(ANOVA) using the general linear model procedure, and regression analysis using the regression procedure of SAS statistics software (SAS Inst., Cary, N.C.).

Virus inoculations and plant analysis. Frozen TropMV infected tobacco leaves were kindly donated by the American Type Culture Collection (Rockville, Md.). For inoculations we thawed TropMV infected tobacco leaves and homogenated in $0.1 \mathrm{M}$ sodium citrate buffer, $\mathrm{pH}$ 7.4; at a ratio of one gram of tissue per $50 \mathrm{~mL}$ of buffer. This solution was applied on leaves previously dusted with 600-mesh carborundum, as described by Soria et al.(1998). Viral solutions were kept on ice until inoculation. TropMV was inoculated on tobacco (Nicotiana benthamiana), which was used as a positive control for the ELISA tests, and mashua accessions AA, MN, $\mathrm{GG}, \mathrm{Acu}$, and $\mathrm{S} / \mathrm{C}$, which were used for visual comparison against un-inoculated plants.

Protein extraction andELISA. Thirteen accessions of mashua brought from Peru were used for ELISA tests. Each sample used for ELISA tests contained the homogenate of at least 3 different tubers of the same accession. Soluble proteins from tubers were extracted according to the method described by Savary and Flores (1994). After precipitation with cold acetone overnight, proteins were centrifuged for $20 \mathrm{~min}$ at $10,000 \mathrm{~g}_{\mathrm{n}}$ and resuspended in Tris buffer (50 mM Trizma, $\mathrm{pH}$ 8). Protein concentration was determined by the Bradford assay (Bradford, 1976).

A monoclonal antibody raised against the TropMV was kindly donated by T.A. Evans, Department of Plant and Soil Sciences, University of Delaware. ELISA tests were done as described by Guimarães et al. (2001). Detection was performed using a chicken anti-IgG coupled to alkaline phosphatase, and the $\rho$-nitrophenylphosphate as a chromogenic substrate (Sigma, Saint Louis, Mo.). Readings were done with a SpectraMax Plus (Molecular Devices, Sunnyvale, Calif.) microplate reader at $405 \mathrm{~nm}$. ELISA tests were replicated twice.

\section{Results}

Tubers of mashua from four Quechua communities were evaluated for the presence of TropMV. Disease symptoms (Fig. 1) include vein clearing, leaf and stem distortion followed by necrosis and reduced growth after a 4-week period (Soria et al., 1998). Various levels of infection were detected by ELISA tests of tubers of 13 accessions. (Fig. 2). All accessions reacted with the TropMV monoclonal antibody, suggesting that most mashua accessions from Quechua farmers have some viral contamination. Tubers were induced to sprout and plants were nondestructively evaluated for the presence of the virus. Table 2 shows the survival rate of plants and the incidence of virus. Accessions from Cuzco had a higher incidence of disease symptoms and lower survival rates than those from Ayacucho. There was significant relationship when tuberseed survival was regressed on disease symptom $\left(r^{2}=0.45^{* * *}, \mathrm{y}=1.02-0.298 \mathrm{x}\right)$. Only $52 \%$ of accessions from Cuzco survived to maturity, of which $87 \%$ displayed visual viral symptoms.
In contrast, $95 \%$ of the tubers from Ayacucho produced mature plants and only $22 \%$ of those had observable disease symptoms.

Those plants that reached maturity were evaluated for tuber yield. Average tuber weight, number of tubers, and total tuber weight produced per plant varied greatly among the different accessions (Table 3). Accessions were found to differ significantly in total tuber weight $(P<0.0001)$ and tuber number $(P<0.0008)$. Accessions OcuandBDE produced more tubers per plant but these tubers were small $2.8 \mathrm{~g} /$ tuber and $3 \mathrm{~g} /$ tuber, respectively. In contrast, accession $\mathrm{MN}$ produced the largest and heaviest tubers (9.7 g/tuber). Accessions $\mathrm{HH}$ and $\mathrm{Kcu}$ failed to produce any tubers. Most of the accessions produced abundant foliage in the greenhouse with the exception of BDE, Fcu, Dcu, and Kcu,
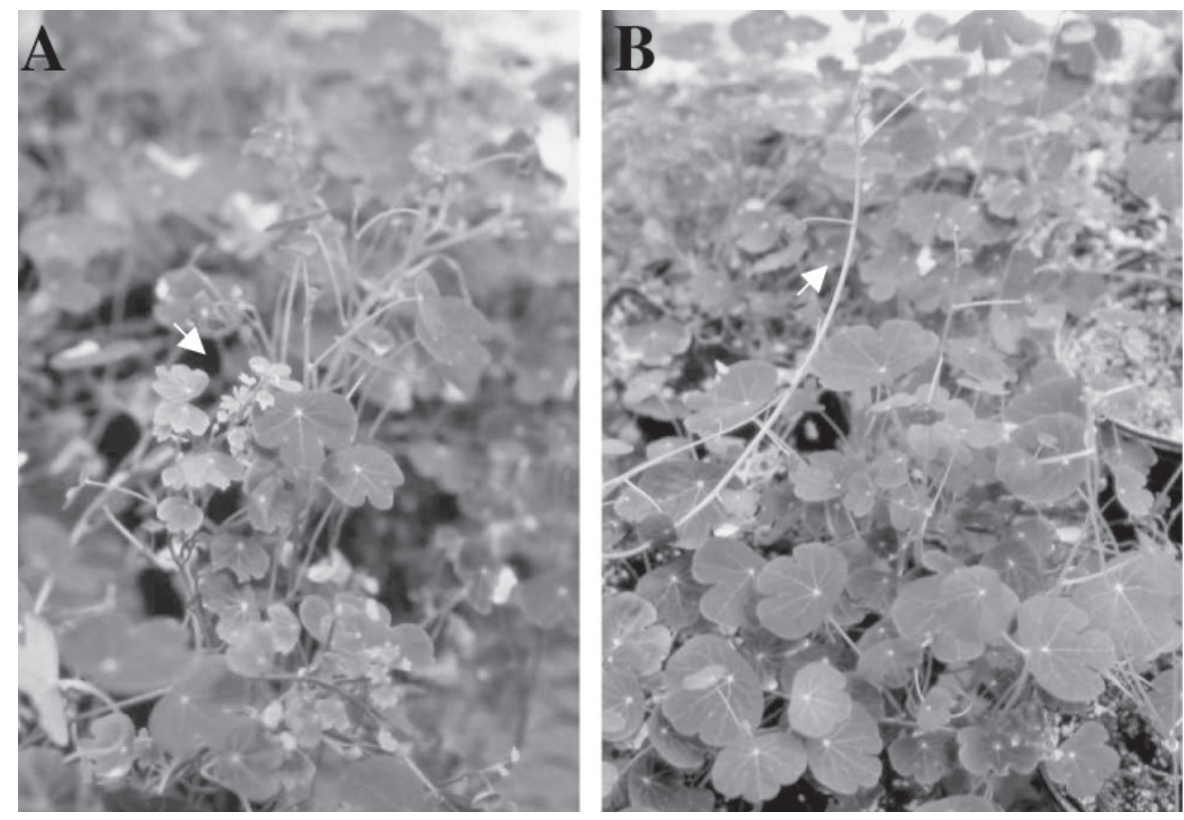

Fig. 1. Tropaeolum mosaic potyvirus (TropMV) symptoms in mashua. (A) Mashua infected with TropMV, arrow points to diseased upper leaves. Stunted stems, vein clearing and downward curling of leaves are symptoms of TropMV disease. (B) Uninfected mashua, arrow points to healthy upper leaves.

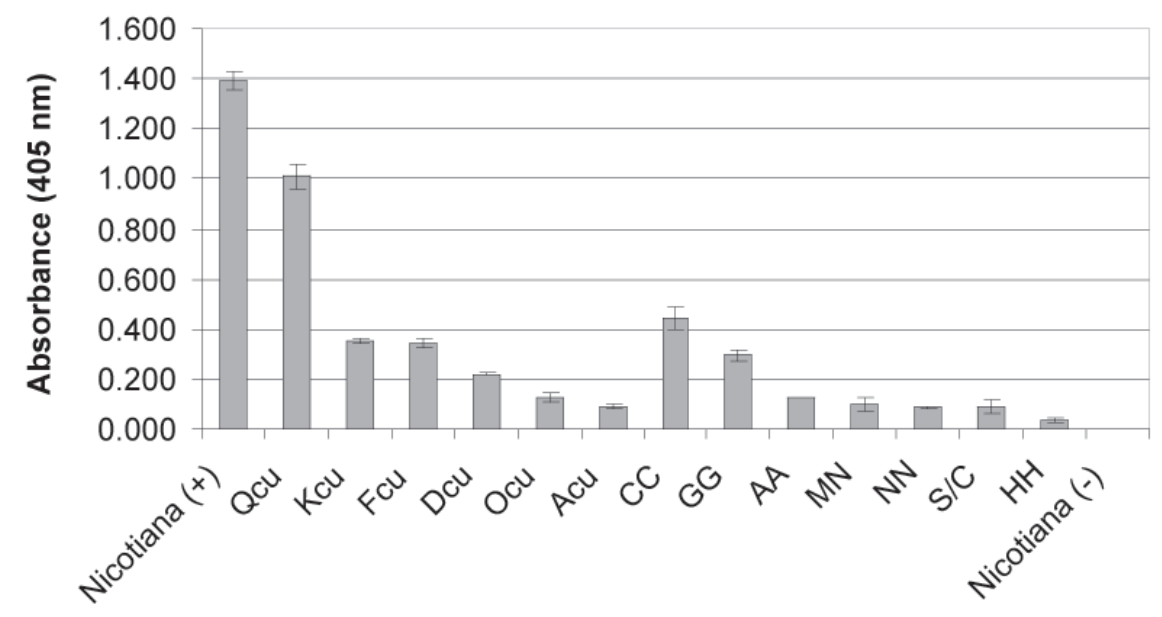

Mashua Accessions

Fig. 2. Tropaeolum mosaic potyvirus (TropMV) titer of 13 mashua accessions as revealed by ELISA. The TropMV antibody was used at a titer of 1:1000. Nicotiana benthamiana infected with TropMV was used as a positive control [Nicotiana $(+)]$; and uninfected $N$. benthamiana as a negative control [Nicotiana (-)]. The negative control was used as a baseline and all absorbances were subtracted from that. Values are means of three tubers \pm SE. 
eases of mashua pointed to two potyviruses, tropaeolum mosaic potyvirus (TropMV) (Soria et al, 1998) and potato virus T (PVT) (Lizárraga et al., 2000). About $74 \%$ of the mashua accessions studied by Soria et al. (1998) from the Santa Catalina Research Station in Quito, Ecuador, were infected by TropMV. It is possible that TropMV has been widely spread throughout the Andes via infected seed tuber. In this paper we demonstrated that the majority of mashua accessions from four Quechua communities showed viral disease symptoms and 13 accessions reacted with the TropMV antibody.

Variation was observed between the accessions from Ayacucho and Cuzco. Fewer tubers from Cuzco produced mature plants than those from Ayacucho. Of the mature plants, more from Cuzco showed viral symptoms than from Ayacucho. Tuber yields were lower for accessions from Cuzco than those from Ayacucho, averaging 7 vs. 11 g per plant, respectively. Causes for such significant variation between mashua accessions from Cuzco and Ayacucho are not entirely understood. It was difficult to

Table 2. Mashua tuber viability and subsequent tropaeolum mosaic potyvirus (TropMV) viral symptoms in foliage.

\begin{tabular}{lcc}
\hline Mashua & $\begin{array}{c}\text { Tubers that } \\
\text { produced } \\
\text { plants (no.) }\end{array}$ & $\begin{array}{c}\text { Visual } \\
\text { virus } \\
\text { symptoms }\end{array}$ \\
\hline AA & 100 & - \\
BDE & 100 & + \\
CC & 66 & + \\
GG & 100 & - \\
HH & 100 & - \\
II & 80 & - \\
MN & 100 & - \\
NN & 100 & - \\
S/C & 100 & - \\
Acu & 100 & - \\
Bcu & 20 & ++ \\
Dcu & 60 & + \\
Fcu & 60 & ++ \\
Kcu & 33 & ++ \\
Jcu & 20 & +++ \\
Ocu & 100 & + \\
Qcu & 20 & +++ \\
\hline
\end{tabular}

z $(-)$ No symptoms; $(+)$ one or two stunted stems, clear veins and curly leaves per plant; $(++)$ less than $50 \%$ stunted stems, clear veins and curly leaves per plant; $(+++)$ necrotic leaves, more than $50 \%$ stunted stems, clear veins and curly leaves per plant. exactly simulate day length in a Pennsylvania greenhouse to Andean conditions.

Availability and quality of seed tubers vary by season and year due to environmental changes. The socioeconomic status of communities also has a noteworthy impact on the diversity of tuber crops. Those communities made up of less affluent families are likely to have limited and lower quality accessions of mashua, or other root and tuber crops. After studying the social and ecological settings that determine diversity of native crops in the region of Paucartambo, Peru, Zimmerer (1996) discovered that the wealthier farmers maintain greater crop diversity than poorer farmers. Another study performed in the region of Picol, Peru, showed that farmers' approaches to obtaining new seed tubers vary according to socioeconomic status (Bianco and Sachs, 1998). Wealthier families purchase seed tubers at the markets in Cuzco city or in the smaller towns of Pisac and Chinchero. In contrast, poorer families generally exchange seeds for their labor. Acquiring better quality seed tubers is a major concern for Andean farmers. Although families save their seed tubers from year to year, they need to replenish their genetic stocks from other farmers or purchase them at local markets and annual seed fairs every 4 or 5 years (Bianco and Sachs, 1998).

Viral diseases are known to cause great yield losses in potatoes and other root and tuber crops (Ngeve and Bouwkamp, 1991; Lot et al., 1998; Hamm and Hane, 1999). A comparative study on 'Russet Norkotah' potato using PLRV diseased seed tubers versus virus-free seed tubers showed $60 \%$ yield reduction and $88 \%$ decrease in marketable yields in the diseased plants (Hamm and Hane, 1999). In this paperwe showed a significant relationship between tuber weight and disease symptoms in greenhouse conditions. We found significant differences in tuber weight and tuber quantity among accessions, suggesting that resistance to viral diseases may exist. Such diversity represents valuable resources for breeding purposes. Afield trial using disease-free seed tubers is necessary to show the extent of viral disease damages on mashua yields in situ, and to account for morphological variations among accessions.

Viral diseases in seed tubers are not necessarily noticeable, unless biochemical tests are

Table 3. Tuber yield for different accessions of mashua grown in pots in the greenhouse.

\begin{tabular}{lccc}
\hline $\begin{array}{l}\text { Mashua } \\
\text { accession }\end{array}$ & $\begin{array}{c}\text { Avg tuber wt } \\
(\mathrm{g}) / \text { plant }(\mathrm{SE})^{\mathrm{z}}\end{array}$ & $\begin{array}{c}\text { Avg no. of } \\
\text { tubers/plant }(\mathrm{SE})\end{array}$ & $\begin{array}{c}\text { Total tuber wt } \\
(\mathrm{g}) / \text { plant }\end{array}$ \\
\hline (SE) & $3.7( \pm 0.2)$ & $3.0( \pm 1.1)$ & $11.2( \pm 0.6)$ \\
AA & $3.0( \pm 1.0)$ & $6.0( \pm 2.1)$ & $15.0( \pm 0.6)$ \\
BDE & $3.4( \pm 0.0)$ & $1.0( \pm 0.0)$ & $3.4( \pm 0.0)$ \\
CC & $5.5( \pm 0.3)$ & $1.8( \pm 0.3)$ & $9.9( \pm 0.7)$ \\
GG & $---\mathrm{y}$ & --- & --- \\
HH & $2.0( \pm 0.0)$ & $0.3( \pm 0.3)$ & $0.6( \pm 0.1)$ \\
II & $9.7( \pm 0.2)$ & $3.0( \pm 0.0)$ & $29.0( \pm 0.7)$ \\
MN & $6.3( \pm 0.0)$ & $0.5( \pm 0.5)$ & $3.1( \pm 0.4)$ \\
NN & $6.1( \pm 0.1)$ & $2.3( \pm 0.3)$ & $14.0( \pm 0.5)$ \\
S/C & $3.9( \pm 0.4)$ & $3.0( \pm 0.7)$ & $11.7( \pm 0.1)$ \\
Acu & $2.1( \pm 0.1)$ & $2.0( \pm 0.6)$ & $4.1( \pm 0.2)$ \\
Dcu & $1.3( \pm 0.0)$ & $1.0( \pm 0.0)$ & $1.3( \pm 0.0)$ \\
Fcu & --- & --- & --- \\
Kcu & $2.8( \pm 0.1)$ & $4.0( \pm 1.0)$ & $11.1( \pm 0.9)$ \\
Ocu & & &
\end{tabular}

${ }^{\mathrm{z}} \pm \mathrm{SE}, \mathrm{n}=4$.

${ }^{\mathrm{y}}$ No tuber formation. performed. We did not observe any detectable changes in tuber morphology in greenhouse conditions. Viral symptoms were only noticeable after sprouting. The use of virus-free seed tubers could be of major importance to Andean farmers. Institutions such as CIP (International Potato Center) and CIAT (International Center for Tropical Agriculture) have recommended the use of virus-free seed tubers and the distribution of decontaminated germplasm accessions (CIP Annual Report, 1994). However, technology for producing virus-free mashua seed tubers has not yet been readily accessible to Andean farmers.

\section{Literature Cited}

Arbizu, C. and M. Tapia. 1994. Andean tubers. Neglected crops: 1492 from a different perspective, p. 149-163. In: J.E. Hernándo and B.J. Léon (eds.). Plant production and protection Ser. 26. FAO, Rome.

Bianco, M. and C. Sachs. 1998. Growing oca, ulluco, and mashua in the Andes: Socioeconomic differences in cropping practices. Agr. Human Values 15:267-280.

Bradford, M.M. 1976. A rapid and sensitive method for the quantitation of microgram quantities of protein utilizing the principle of protein-dye binding. Anal. Biochem. 7:248-254.

CIPAnnual Report. 1994. "Lost" Andean roots and tubers travel ancient trade routes, p. 16-20. Centro Internacional de la Papa, La Molina, Lima, Peru.

Da Graca, J.V. and Martin, M.M. 1977. A mosaic disease of nasturtium occurring in South Africa. Phytopath. Z. 88:276-279.

Delhey, R. and T. Monasterios. 1977. A mosaic disease of isanu, (Tropaeolum tuberosum) from Bolivia. Z. Pflanzenkr. Pflanzenschutz 84:224-231.

Flores, H.E., T.S. Walker, R.L. Guimarães, H.P. Bais, and J.M. Vivanco. 2003. Andean root and tuber crops: Underground rainbows. HortScience 38:161-167.

Guimarães, R.L., L.H. Marcellino, M.F.G. de Sá, and D.C. Monte. 2001. A storage protein gene from taro shows tuber-specific expression in transgenic potato. Phys. Plant. 111:182-187.

Hamm, P.B. and D.C. Hane. 1999. Effects of seedborne potato leafroll virus on Russet Norkotah potato. Plant Dis. 83:1122-1124.

Jensen, D.D. 1950. Nasturtium mosaic, a virus disease of Tropaeolum majus L. in California. Phytopathology 40:967.

Lizárraga, C., M. Querci, M. Santa Cruz, I. Bartolini, and L.F. Salazar. 2000. Other natural hosts of Potato virus T. Plant Dis. 84:736-738.

Lot, H., V. Chovelon, S. Souche, and B. Delecolle. 1998. Effects of onion yellow dwarf and leek yellow stripe viruses on symptomatology and yield loss of three french garlic cultivars. Plant Dis. 82:1381-1385.

National Research Council. 1989. Lost crops of the Incas; little known plants of the Andes with promise for worldwide cultivation, p. 66-73. In: Mashua. National Academy Press, Wash., D.C.

Ngeve, J.M and J.C. Bouwkamp. 1991. Effects of sweet potato virus disease (SPVD) on the yield of sweet potato genotypes in Cameroon. Expl. Agr. 27:221-225.

Savary, B.J. and H.E. Flores. 1994. Biosynthesis of defense-related proteins in transformed root cultures of Trichosanthes kirilowii Maxim. var. japonicum (Kitam.). Plant Physiol. 6:1195-1204.

Silberschmidt, K. 1953. Studies on a mosaic of nasturtium occurring in Brazil. Phytopathology 43:304-308.

Smith, K.M. 1950. Somenew virus diseases of ornamental plants. J. Royal Hort. Soc. 75:350-353.

Soria, S.L., R. Vega, V.D. Damsteegt, S.L. Kitto, and T.A. Evans. 1998. Occurrence and partial characterization of a new mechanically transmissible virus in Mashua from the Ecuadorian Highlands. Plant Dis. 82:69-73.

Zimmerer, K. 1996. Changing fortunes: Biodiversity and peasant livelihood in the Peruvian Andes, p. 12-73. Univ. Calif. Press. Berkeley. 